\title{
IJPHN
}

\section{The Effect of the Provision of Bagea Enriched with Sea Urchin Gonads on Weight Gain in Toddlers of the Bajo Ethnic}

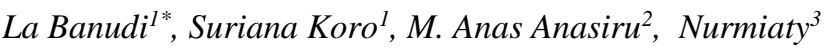 \\ ${ }^{1}$ Lecturer Nutrition of Department, Health Polytechnic of Kendari. Southeast Sulawesi \\ ${ }^{2}$ Lecturer Nutrition of Department, Health Polytechnic of Gorontalo \\ 3. Lecturer Midwifery of Department, Health Polytechnic of Kendari. Southeast Sulawesi
}

\author{
*Corresponding Author: \\ La Banudi \\ E-mail: labanudilaban@gmail.com
}

\begin{abstract}
Cassava starch extract and sea urchin gonads can be used as ingredients for making various kinds of food formulas. This study aimed to develop cassava starch extract as a formula for making bagea added with sea urchin gonads which are rich in nutrients to make it good for child. This study was aimed at analyzing the effect of the provision of bagea enriched by sea urchin gonads on weight gain in toddlers of the Bajo community. In making the formula of bagea, the researchers used a quasi-experimental design. After the data were collected, they were then checked for feasibility, coded, and reduced. Furthermore, data were presented in tabular form, showing percentage and frequency, and analyzed using statistical tests. Before the t-test was carried out, a homogeneity test of the sample was first conducted which showed that $\mathrm{p}$ value $<0.05$ that there was no difference in consumption between the treatment groups. Consuming bagea enriched with sea urchin gonads has an effective effect on weight gain in toddlers of the Bajo tribe (p $<0.001$ ). Furthermore, the provision of additional food from a government program (in form of biscuits) has also an effect on weight gain in toddlers of the Bajo tribe $(\mathrm{p}<0.001)$. Apart from that, the researcher also found a difference between the consumption of bagea enriched with sea urchin gonads and the provision of additional food (biscuits) from the government program on weight gain in toddlers of the Bajo tribe $(\mathrm{p}<0.001)$. Suggestions for health workers, namely nutrition programmers, to use bagea, a local Southeast Sulawesi food that has high nutritional value to improve nutritional status (weight gain) in toddlers.
\end{abstract}

Keywords: Body weight, Bagea, Toddlers (Children Under-Five)

\begin{abstract}
Abstrak
Ekstrak kanji singkong dan gonad landak laut dapat digunakan sebagai bahan pembuatan berbagai macam makanan formula. Penelitian bertujuan untuk mengembangkan ekstrak kanji singkong sebagai formula pembuatan bagea yang ditambahkan dengan gonad landak laut (Sea urchins) yang kaya akan zat gizi sehingga cocok untuk anak. Tujuan penelitian, menganalisis pengaruh pemberian bagea yang dipekaya gonad landak laut pada anak Batita suku Bajo terhadap kenaikan berat badan. Pada pembuatan formula bagea menggunakan desain quasi eksperiment. Setelah data dikumpulkan, diperiksa kelayakannya, dienteri, dibersihkan, selanjutnya data disajikan dalam bentuk tabel, persentase, frekuensi dan dianalisa dengan menggunakan uji statistic. Sebelum dilakukan uji perbedaan, terlebih dahulu dilakukan uji homogenitas sampel menunjukkan bahwa nilai $P<0,05$ bahwa tidak ada perbedaan konsumsi antar kelompok perlakuan. Ada pengaruh Konsumsi bagea ditambah Gonad landak laut lebih efektif menaikkan berat badan anak Batita pada suku Bajo p<0,001. Ada pengaruh pemberian makanan tambahan program pemerintah (biskuit) terhadap kenaikkan berat badan anak batita suku Bajo p<0,001. Ada perbedaan antara Konsumsi bagea ditambah Gonad landak laut) dengan program pemerintah (biskuit) terhadap peningkatan berat badan anak batita Suku Bajo p<0,001. Saran yang diajukan Pada petugas untuk progremer perbaikan gizi agar menggunakan bagea yang tinggi nilai gizi dan sebagai makanan local Sulawesi Tenggara perbaikan status gizi (kenaikan berat badan) pada anak batita.
\end{abstract}

Kata Kunci: Berat Badan, Bagea, Batita 


\section{Introduction}

The toddler period is a period of rapid growth and development so that it is sometimes called the golden period or the critical period. The golden period can be realized if at this time children under three years of age (toddlers) get the appropriate nutritional intake for optimal growth and development. Conversely, if they do not get food according to their nutritional needs in this time, the golden period will turn into a critical period that may disrupt the growth and development of the children, both at this time and in the future $(1,2)$.

The nutritional status of children under five is one indicator that describes the level of community welfare. One way of assessing the nutritional status of children under five is anthropometric measurement using the index of body weight for age (BW/A). Data from the results of basic health research in 2013 showed that the incidence of underweight and severely underweight has increased from 2007 until 2013. Cases of underweight in 2007 were $4.5 \%$. It increased by $5.7 \%$ in 2013 . Furthermore, cases of severely underweight in 2007 were $13.0 \%$. It increased by $13.9 \%$ in 2013 . Of the 34 provinces in Indonesia, Southeast Sulawesi is in the 13th position in which its prevalence of underweight is $26 \%$, which exceeds the national prevalence, namely $19.6 \%$ (3).

There are several factors that affect the nutritional status. One of them is unsustainable nutritional intake. One of the steps that can be taken is to improve parenting behavior by empowering families. This method can improve family skills in providing additional food for their babies, especially during the first time feeding other than breast milk, considering that supplementary feeding is a highly important factor because babies who do not have sufficient nutritional intake may experience a decrease in the immune system which will later be susceptible to disease and nutritional problems. Apart from nutrient intake, infection also affects nutritional status. Malnutrition in general causes disruption in the process of growth, energy production, body defense, behavior, body structure, and brain function (4-6).

The food consumption factor is a direct cause of the incidence of malnutrition in children under five. This is due to the consumption of food that does not meet the amount and composition of nutrients for meeting the requirements of balanced nutrition, namely variousness, needs, cleanliness, and safety. Therefore, it will have a direct impact on the growth and development of toddlers (7-10).

The Supplementary Feeding Program (Indonesian: Program Pemberian Makanan Tambahan (PMT) is a program initiated by the Ministry of Health of the Republic of Indonesia by providing food products (in form of biscuits) to the families in need. However, this program has not yet reached the target for good nutritional status in toddlers in the area of Kendari. This is known from interviews with many mothers whose children are malnourished because some toddlers do not like the biscuit (the product of this program) because it is a popular food and have been given to children for a longtime causing boredom in children. They prefer additional local food from their mothers.

A study conducted by Salma (2016) showed that the Fe content in 100 grams of sea urchin gonads (Diadema Setosum) is $1.00 \mathrm{mg}$, which is almost equal to that of salmon, namely $1.50 \mathrm{mg}$. Therefore, sea urchins are very suitable as supplementary food for toddlers who need the appropriate $\mathrm{Fe}$. Fe content is 
needed by toddlers for the development of hemoglobin $(\mathrm{Hb})$, which is an oxygen transporter to tissues. Furthermore, a study conducted by Salma on the potential of sea urchin gonads to improve nutritional status also showed that the provision of $200 \mathrm{mg} / \mathrm{kg}$ of sea urchin gonads can increase body weight by 0.78 grams on day 10 and increase by $1.7 \mathrm{~kg}$ on day 17 (11).

This study aimed at analyzing the effect of the provision of bagea enriched by sea urchin gonads on weight gain in toddlers by producing a formula of bagea enriched with sea urchin gonads. The results of the formula are then given to toddlers to find out its effect on changes in body weight. Furthermore, the results will be used as a reference for nutritional workers in the area of the Bajo tribe in providing services or nutrition improvement, especially for improving nutritional status in toddlers.

\section{Methods}

In this study, an analytical study using a quasi-experimental method was applied. This study was carried out in the working area of Soropia and Lalonggasumeeto Health Centers. This area is a coastal area and inhibited by the Bajo tribe. This study was conducted for 6 months from June to December 2020. The total of samples in this study was 105 toddlers who were divided into 3 different treatment groups, namely a treatment group of bagea provision, government biscuits provision, and not getting treatment and were followed up for 3 (three) consecutive months. Each group consisted of 35 toddlers.

The nutritional content of each primary package of biscuits (4 pieces/40gr) of additional food for toddlers contained a minimum of 160 calories, 3.2-4.8 grams of protein and 47.2 grams of fat, while bagea (4 pieces/40 grams) contained a minimum of 228.1 calories, 3.9 grams of protein, and 10.96 grams of fat.

Primary data were collected using direct interviews with mothers of toddlers. Anthropometric data measurements were carried out before and after the treatment. Children's weight measurement using a digital scale. The first weight measurement was carried out on the mother and her toddler together, then only on the mother. To get the result, the first measurement was subtracted by the second measurement. Measurements were made for each treatment group. This measurement was carried out every month during the treatment, namely the first, second, and third months. Eating patterns were obtained by using the Food Frequency Questionnaire (FFQ) to determine the type and frequency of food consumed by each child. Each type and frequency of food has a value. In the end, the consumption value of each child can be known. Primary data covered the identity, age, and weight of the respondent. Meanwhile, secondary data were data concerning the toddlers obtained from Soropia and Lalonggasumeeto Health Centers, covering data of characteristics. For statistical analyses, the researcher applied Paired Sample T-Test, and Independent T-Test.

\section{Results}

This study was conducted on toddlers from the Bajo tribe in the working area of Soropia and Lalonggasumeeto Health Centers. The characteristics of samples can be seen in Table 1 below. 
Table 1. The Characteristics of Research Respondents

\begin{tabular}{|c|c|c|c|c|c|c|c|c|}
\hline \multirow[t]{3}{*}{ Variable } & \multicolumn{6}{|c|}{ Intervention } & \multicolumn{2}{|c|}{ Total } \\
\hline & \multicolumn{2}{|c|}{ Control } & \multicolumn{2}{|c|}{ Biscuit } & \multicolumn{2}{|c|}{ Bagea } & \multirow[b]{2}{*}{$\mathbf{N}$} & \multirow[b]{2}{*}{$\%$} \\
\hline & $\mathbf{n}$ & $\%$ & $\mathbf{n}$ & $\%$ & $\mathbf{n}$ & $\%$ & & \\
\hline \multicolumn{9}{|l|}{ Mother's Age } \\
\hline$<20$ Years Old & 0 & 0 & 1 & 2.9 & 3 & 8.6 & 4 & 3.8 \\
\hline $20-35$ Years Old & 32 & 91.4 & 33 & 94.2 & 28 & 80.0 & 93 & 88.6 \\
\hline > 35 Years Old & 3 & 8.6 & 1 & 2.9 & 4 & 11.4 & 8 & 7.6 \\
\hline \multicolumn{9}{|c|}{ Mother's Education Level } \\
\hline Elementary School & 12 & 34.3 & 0 & 0 & 9 & 25.7 & 21 & 20.0 \\
\hline Junior High School & 6 & 17.1 & 1 & 2.9 & 5 & 14.3 & 12 & 11.4 \\
\hline Senior High School & 17 & 48.6 & 32 & 91.4 & 20 & 57.1 & 69 & 65.7 \\
\hline Higher Education & 0 & 0 & 2 & 5.7 & 1 & 2.9 & 3 & 2.9 \\
\hline \multicolumn{9}{|l|}{ Mother's Occupation } \\
\hline Housewife & 35 & 100 & 34 & 97.1 & 34 & 97.1 & 103 & 98.1 \\
\hline Private Employee & 0 & 0 & 0 & 0 & 1 & 2.9 & 1 & 1.0 \\
\hline Public Servant & 0 & 0 & 1 & 2.9 & 0 & 0 & 1 & 1.0 \\
\hline \multicolumn{9}{|l|}{ Toddler's Gender } \\
\hline Male & 21 & 60.0 & 17 & 48.6 & 18 & 51.4 & 56 & 53.3 \\
\hline Female & 14 & 40.0 & 18 & 51.4 & 17 & 48.6 & 49 & 46.7 \\
\hline
\end{tabular}

Table 1 shows that in the category of mother's age, most of the samples have the age of $20-35$ years, namely 93 of 105 people $(88.69 \%)$. Meanwhile, samples with the age of $<20$ years are 4 people $(3.8 \%)$ and those with the age of $>35$ are 8 people $(7.6 \%)$.

In the category of mother's education, most of the samples have a senior high school education, namely 69 of 105 people $(65.7 \%)$. The least is those possessing a higher education (12), namely 3 people (2.9\%). Meanwhile, samples who have an elementary school education are 21 people (20.0\%) and those who have a junior high school education are 12 people (11.4\%).

In the category of mother's occupation, most of the samples have a job as a housewife, namely 103 of 105 people $(98.1 \%)$. The least is those having a job as a public servant, namely 1 person (1.0\%). Meanwhile, samples who have a job as a private employee are 1 person $(1.0 \%)$. In the category of the gender of the toddlers, 56 of them are male $(53.3 \%)$, and 49 of them are female (46.7\%). During the treatment, data was collected on eating patterns. Eating patterns were obtained by using the Food Frequency Questionnaire (FFQ) to determine the type and frequency of food consumed by each child. Each type and frequency of food has a value. In the end, the consumption value of each child can be known. The difference of eating patterns between the Bagea and Biscuit interventions can be presented in Table 2 . Based on table 2, the value of eating patterns when giving bagea, which was 309.2 with a standard deviation of 32.0 , and the treatment of giving biscuits, which was 305.1 with a standard deviation of 36.0. After analyzing the data using the Wilcoxon test ( $\alpha 0.05$ ), the treatment of bagea and biscuits obtained a $\mathrm{p}$ value of 0.599 , so there was no difference in eating patterns between the treatment of bagea and biscuits.

Data collection on the level of consumption was carried out when the treatment was given to the sample. Based 
on the statistical test, the p-value $<0.05$ indicated that there was no difference in the level of sample consumption at the time of the study. Table 3 illustrates that samples' body weight before being given the treatment was $9.31 \pm 1.65 \mathrm{in}$ the control group, $9.94 \pm 2.12$ in the group given the biscuits, and $9.42 \pm 1.69$ in the group given bagea. After the treatment, the average body weight in the control group, biscuits, and bagea were increased by $0.25 \pm 0.19 \mathrm{~kg}, 0.46 \pm 0.43$ $\mathrm{kg}$, and $0.82 \pm 0.22 \mathrm{~kg}$, respectively. Using the Paired T-Test, the obtained pvalue was $<0.001$, meaning that the provision of biscuit and bagea has an effect on changes in body weight. After being analyzed using ANOVA and Post Hoc Test, the obtained p-value was $<0.001$, meaning that there is a significant difference in body weight gain from all treatment groups.

Table 2. Differences in Eating Patterns Values at the Control, Bagea and Biscuit Intervention Groups

\begin{tabular}{lcc}
\hline \multicolumn{1}{c}{ Intervention } & Eating patterns score & p-value \\
\hline Control & $307.7 \pm 35.0$ & \\
Bagea & $309,2 \pm 32,0$ & 0,599 \\
Biscuit & $305,1 \pm 36,0$ & \\
\hline
\end{tabular}

Table 3. The Effect of the Provision of Bagea and Biscuits on Weight Gain in Toddlers of the Bajo Tribe

\begin{tabular}{|c|c|c|c|c|}
\hline \multirow[b]{2}{*}{ Treatments } & \multicolumn{2}{|c|}{ Body Weight (kg) } & \multirow{2}{*}{$\begin{array}{l}p \text {-value } \\
\text { (within } \\
\text { group) }\end{array}$} & \multirow{2}{*}{$\begin{array}{c}p \text {-value } \\
\text { (between } \\
\text { groups) }\end{array}$} \\
\hline & Before & After & & \\
\hline Control & $9.31 \pm 1.65$ & $9.56 \pm 1.68$ & $<0.001$ & \\
\hline Given Biscuits & $9.94 \pm 2.12$ & $10.39 \pm 2.08$ & $<0.001$ & $<0.001$ \\
\hline Given Bagea & $9.42 \pm 1.69$ & $10.24 \pm 1.68$ & $<0.001$ & \\
\hline
\end{tabular}

\section{Discussion}

\section{The Differences in Toddlers' Body Weight}

Bagea cake is a snack food that is very well known and common in Kendari. This cake has a dry texture and a bit hard. It tastes sweet and savory. From its basic ingredients, this cake is made from sago. However, in this study, it is modified with cassava flour and sea urchin gonads. Besides it tastes good, this cake is also unique because it is almost similar to biscuits. WHO (1996) defines snack food as food and beverages that are prepared or sold by street vendors on the side of the road or other crowded places (13).

In this study, bagea cakes are made from the results of a trial that produced a pretty good product in terms of color, aroma, texture, and taste. This trial took about 1 day. The texture and taste of bagea cake are highly important in increasing the appetite of toddlers because taste sensitivity is influenced by the texture of the food. Foods that are solid or thick will provide slower stimulation to the senses. Texture also affects the appearance of the food served. Therefore, the texture of this bagea is very suitable for toddlers. (6, 14).

The results of this study showed that the average body weight of toddlers before being given the treatment was $9.3114 \pm 1.64813$ in the control group, $9.9371 \pm 2.11870$ in the group given the biscuits, and $9.4171 \pm 1.69853$ in the group given bagea. After being given the treatment, their average body weight was 
$9.5571 \pm 1.67478$ in the control group, $10.3943+2.08269$ in the group given the biscuits, and $10.2371 \pm 1.68070$ in the group given bagea. Furthermore, after being analyzed using the Paired T-Test, the obtained p-value was 0.000 , meaning that the provision of biscuit and bagea has an effect on changes in body weight. This study was in line with other studies that supplementary food in the form of milk can increase body weight (6)

Bagea enriched with sea urchin (Diadema Setosum) gonads is used as a food supplement for toddlers. This additional food is consumed at any given time or for free time. This additional food as a snack can meet the energy needs for a day (14).

The provision of bagea enriched with sea urchin (Diadema Setosum) gonads can more increase the bodyweight $20 \%$ higher than that of biscuits from the government. This finding is in line with the previous study that the group that is given the intervention with the dose of $200 \mathrm{mg} / \mathrm{kg}$ has higher improvement in body weight than the group that is given the intervention with the dose of 100 $\mathrm{mg} / \mathrm{kg}$. On the other hand, the control group experiences a significant reduction in body weight ( $\mathrm{p}$-value $=$ $0.001)(15,16)$.

Based on the test for finding out the nutritional content, 100 grams of bagea contain $570.49 \mathrm{kcal}$ of energy, 9.875 grams of protein, 27.41 grams of fat, and 71.08 grams of carbohydrates. By considering this nutritional content, bagea enriched with sea urchin (Diadema Setosum) gonads contains higher nutrients than biscuits. Furthermore, another study also shows an increase in energy consumption as much as $505.27 \pm 273.80 \mathrm{kcal}$ and an increase in body weight as much as 7.03 $\pm 2.10 \mathrm{~kg}$.

Besides containing macronutrients, this bagea also contains micronutrients, namely vitamins and minerals, which can help the body's metabolic processes for pregnant women, such as vitamin A, vitamin $\mathrm{B} 1$, vitamin $\mathrm{B} 2, \mathrm{Fe}, \mathrm{Mg}$, and $\mathrm{Zn}$.

\section{The Differences in the Effect of the Provision of Bagea and Biscuits on Weight Gain in Toddlers of the Bajo Tribe}

Intervention in form of the provision of bagea was conducted by the researchers to increase the bodyweight of toddlers experiencing underweight. The provision of bagea is an effort to overcome nutritional problems in underweight toddlers, in which bagea is given as a snack. Functional Mixed Food Ingredients are food ingredients that can provide beneficial effects on health in addition to the nutritional effects that food principally has (17-19).

Bagea is a traditional food that has unique characteristics and has various types, that reflect the natural potential of the Southeast Sulawesi Province. It is not only for meeting nutritional needs but also for maintaining human relationships. It is a symbol of the identity of a particular community and can also be sold and promoted to support tourism that can strengthen the income of the region (20).

The results of the statistical test using the ANOVA showed that the obtained pvalue was 0.000 , meaning that there is a significant difference in body weight gain from all treatment groups. One of the important nutrients in biscuits from the government as complementary foods is protein because it plays a role in the growth and maintenance of body cells. In addition, Vitamin A also plays a role in the function of the immune system and protects the integrity of the epithelial cells of the skin layer, the surface of the eyes, the inside of the mouth, and the respiratory tract (Juhartini, 2015). 
Meanwhile, bagea contains protein. If being consumed by children, the protein composed of amino acids will be used by the body for growth and development (21).

Bagea is ready to use food (RUF) that is suitable for preventing and treating underweight in toddlers and has the potential to increase nutritional yield (22). Over the recent years, concerns over energy suitability and energy density in the cereal/legume blend to meet dietary nutrition have risen. However, there are limitations to increasing the nutrient and energy density of porridge in the absence of technological advances $(12,23)$.

In this study, there was a difference in the average weight gain of toddlers in three months. The average weight gain was $0.8200 \pm 0.21936$ in the bagea provision group, $0.4571 \pm 0.4246$ in the biscuit provision group, and $0.2486 \pm$ 0.1900 in the control group. Measurements on the anthropometric index of body weight for age (BW/A) before and after being given the biscuits from the government showed that more children experienced changes in body weight with an increase of about $1-3$ ounces. This is directly proportional to the level of consumption of toddlers, in which these toddlers consume the biscuits from the government according to the determined standards. The provision of this food will have a positive effect on weight gain so that it will prevent stunting $(24,25)$.

In making bagea sasigo, it needs 60 grams of sago, 40 grams of cassava, and additional 20 grams of sea urchin gonads. Meanwhile, the biscuits from the government have a weight of 40 grams (14).

A study conducted by Salma in 2016 showed that the Fe content (26) in 100 grams of Diadema Setosum gonads was $1.00 \mathrm{mg}$. It is almost equal to that of salmon, namely $1.50 \mathrm{mg}$. Therefore, the gonads of Diadema Setosum are highly suitable as supplementary food in the diet of child women who require appropriate Fe. In addition, Fe is highly needed for the development of hemoglobin $(\mathrm{Hb})$, which is an oxygen transporter to tissues (27).

\section{Conclusion}

Consuming bagea enriched with sea urchin (Diadema Setosum) gonads has an effect on weight gain in toddlers of the Bajo tribe. The provision of additional food from a government program (in form of biscuits) has also an effect on weight gain in toddlers of the Bajo tribe. There is a difference between the consumption of bagea enriched with sea urchin gonads and the provision of additional food (biscuits) from the government program on weight gain in toddlers of the Bajo tribe.

Its is suggested that Health workers (nutrition improvement programmers) are recommended to use bagea as one of the additional feeding interventions to improve nutritional status (weight gain) in toddlers. The results of this study are recommended to be developed in further studies, especially those concerning the provision of additional food in the form of bagea by providing treatment to other targets, such as breastfeeding mothers, pregnant women, infants, or young women.

\section{References}

1. Depkes RI. Petunjuk Pelaksanaan Pemberian Makanan Pendamping Air Susu Ibu (MP ASI. Lokal. In: kesehatan D, editor. Jakarta2006.

2. Roberts SB, Franceschini MA, Silver RE, Taylor SF, de Sa AB, Có R, et al. Effects of food supplementation on cognitive function, cerebral blood 
flow, and nutritional status in young children at risk of undernutrition: Randomized controlled trial. bmj. 2020;370.

3. Riskesdas. Kejadian gizi. Indonesia2013.

4. Almatsier S. Prinsip dasar ilmu gizi: Gramedia Pustaka Utama; 2006.

5. Banudi L. Gizi Kesehatan Reproduksi: Buku Saku Bidan. Jakarta: EGC; 2013.

6. Das JK, Salam RA, Saeed M, Kazmi FA, Bhutta ZA. Effectiveness of interventions for managing acute malnutrition in children under five years of age in low-income and middle-income countries: a systematic review and meta-analysis. Nutrients. 2020;12(1):116.

7. Ayuputri. Ilmu gizi. Yogyakarta: Nuha medika; 2010.

8. Banudi L, Santoso B, Leksono P, Rantesalu M, Palutturi S. The Development of Early Detection Tool for Stunting Prediction. Medico Legal Update. 2020;20(4):1285-91.

9. Walters $\mathrm{CN}$, Rakotomanana $\mathrm{H}$, Komakech JJ, Stoecker BJ. Maternal determinants of optimal breastfeeding and complementary feeding and their association with child undernutrition in Malawi (2015-2016). BMC public health. 2019;19(1):1-12.

10. Okoth JK, Ochola SA, Gikonyo NK, Makokha A. Development of a nutrient-dense complementary food using amaranth-sorghum grains. Food science \& nutrition. 2017;5(1):86-93.

11. Toruntju SA, Banudi L, Purnomo Leksono MR, Salma WO. The Influence of Wedge Sea Hare (Dolabellaauricularia) Extract and Papaya Juice on Hemoglobin $(\mathrm{Hb})$ and Feritin Levels of Mice Strain (Balb/C) with Anemia. Medico Legal Update. 2020;20(1):1347-52.
12. Cohuet S, Marquer C, Shepherd S, Captier V, Langendorf C, Ale F, et al. Intra-household use and acceptability of Ready-to-UseSupplementary-Foods distributed in Niger between July and December 2010. Appetite. 2012;59(3):698-705.

13. Santosa H. HIDROLISA ENZIMATIK PATI TAPIOKA DENGAN KOMBINASI PEMANAS MICROWAVEWATER BATH PADA PEMBUATAN DEKSTRIN. Momentum. 2010;6(2).

14. Banudi L, Anasiru MA, Petrus P, Leksono P. Formulasi Bagea Berbahan Ekstrak Tepung Singkong dan Gonad Diadema Setosum (Sea urchins) sebagai Makanan Alternatif pada Ibu Hamil. Health Information: Jurnal Penelitian. 2017;9(2):65-71.

15. Salma WO, Yusuf I, Karo M, Banudi L. The effect of Sea urchin (Diadema setosum) gonad extract on IgM and IgG antibodies production in $\mathrm{BALB} / \mathrm{c}$ mice infected by Salmonella typhi. Jurnal Gizi Klinik Indonesia. 2018;14(3):93-8.

16. Bukusuba J, Kaaya AN, Atukwase A. Modelling the impact of stunting on child survival in a rural Ugandan setting. BMC nutrition. 2018;4(1):110.

17. Juhartini J. PENGARUH PEMBERIAN MAKANAN TAMBAHAN BISKUIT DAN BAHAN MAKANAN CAMPURAN KELOR TERHADAP BERAT BADAN DAN HEMOGLOBINStudi Pada Balita Dengan Status Gizi Kurus Di Wilayah Kerja Puskesmas Kalumpang Kota Ternate Tahun 2015. Hospital Majapahit (JURNAL ILMIAH KESEHATAN POLITEKNIK KESEHATAN MAJAPAHIT MOJOKERTO). 2016;8(2). 
18. Toruntju SA, Banudi L, Leksono P, Rahmat M, Salma WO, editors. Identification of secondary metabolite contents on marine rabbit extract (dolabella auricularia). IOP Conference Series: Earth and Environmental Science; 2020: IOP Publishing.

19. Abdulahi A, Shab-Bidar S, Rezaei S, Djafarian K. Nutritional status of under five children in Ethiopia: a systematic review and meta-analysis. Ethiopian journal of health sciences. 2017;27(2):175-88.

20. Nurhayati ED, Mulyana VIE, Meilawati A. Inventarisasi Makanan Tradisional Jawa Serta Alternatif Pengembangannya. Penelitian Guru Besar Universitas Yogyakarta Yogyakarta. 2013.

21. Anugraheni HS, Kartasurya MI. Faktor risiko kejadian stunting pada anak usia 12-36 bulan di Kecamatan Pati, Kabupaten Pati: Diponegoro University; 2012.

22. Owino V. Why lipid-based ready to use foods (RUF) must be key components of strategies to manage acute malnutrition in resource poor settings Victor Owino. 2010.

23. Wang RJ, Trehan I, LaGrone LN, Weisz AJ, Thakwalakwa CM, Maleta KM, et al. Investigation of food acceptability and feeding practices for lipid nutrient supplements and blended flours used to treat moderate malnutrition. Journal of nutrition education and behavior. 2013;45(3):258-63.

24. Banudi L, Santoso B, Leksono P, Rantesalu M, Palutturi S. Factors Related to Stunting in Toddlers Aged 6-24 Months. Medico Legal Update. 2020;20(4):1582-7.

25. Salma WO, Wahyuni S, Yusuf I, Haya L, Yusuf I, Asad S. Immune nutrient content of sea urchin (Diadema Setosum) gonads. Int $\mathrm{J}$
Nutr Food Sci, 2016a. 2016;5(5):330-6.

26. Korompot AR, Fatimah F, Wuntu AD. Kandungan Serat Kasar Dari Bakasang Ikan Tuna (Thunnus SP.) Pada Berbagai Kadar Garam, Suhu Dan Waktu Fermentasi. Jurnal Ilmiah Sains. 2018;18(1):31-4.

27. Salma W. Pengaruh Nutrisi dan Efek Ekstrak Gonad Diadema Setosum (Sea urchins) Trhadap Produksi Interveron (IFN) y, Interleukin (IL10) dan Ekspresi Gen FOXP3 pada Mencit Strain BALB/c yang dimutasi dengan Lipolisakarida (LPS). Makassar; 2016. 